\title{
¿Cómo influye la desorganización familiar en el consumo de drogas de los hijos? Una revisión
}

\section{How does family disorganization influence children's drug use? A review}

\author{
Elisardo Becoña *,**; Úrsula Martínez ${ }^{*}$; \\ Amador Calafat ${ }^{* *}$; MONTSE JUAN*; Mariangels DUCH ${ }^{* *}$; \\ José Ramón FernándeZ-HERMIDA**
}

\author{
* Universidad de Santiago de Compostela, España \\ ${ }^{* \star}$ European Institute of Studies on Prevention (IREFREA), España

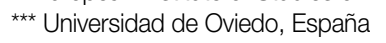

\author{
Enviar correspondencia a: \\ Elisardo Becoña. Universidad de Santiago de Compostela. \\ Facultad de Psicología, Departamento de Psicología Clínica y \\ Psicobiología. \\ Campus Sur. \\ 15782 Santiago de Compostela, España. \\ Tel.: +34-881813729 \\ E-mail: elisardo.becona@usc.es
}

\section{Resumen}

Desde hace tiempo sabemos que diversos aspectos del funcionamiento familiar pueden incidir de modo importante en el consumo de drogas de los hijos tanto promoviendo la protección y resiliencia como induciendo el riesgo hacia el consumo. Esta revisión analiza los estudios publicados en los últimos 30 años sobre la influencia de la desorganización familiar en el consumo de drogas de los hijos. En función de los resultados encontrados consideramos que las familias desorganizadas (caracterizadas por enfermedad mental de los padres, consumo de sustancias de los padres y/o familias no intactas) tienen más probabilidades de tener hijos consumidores de drogas, tanto legales como ilegales. Finalmente, señalamos la necesidad de mejorar la conceptualización y evaluación del término desorganización familiar, asi como otras limitaciones metodológicas encontradas en los distintos estudios empíricos revisados.

Palabras clave: desorganización familiar, estructura familiar, tabaco, alcohol, heroína, drogas, adolescencia, revisión.

\section{Abstract}

It is well known that various aspects of family functioning can influence children's drug use, both by promoting resilience and by increasing the risk of use. This review examines studies published in the last 30 years about the influence of family disorganization on children's drug use. Based on the results, we consider that disorganised families (charactirezed by parents' mental illness, parents' substance use and/or non-intact families) are more likely to have children who are drug users, both legal and illegal. Finally, we stress the need to improve the conceptualization of family disorganization and its assessment, and point out other methodological limitations found in the empirical studies reviewed.

Key words: family disorganization, family structure, smoking, alcohol, heroin, drugs, adolescence, review. 
L a familia constituye un componente clave en el desarrollo de las personas ya que es uno de los primeros elementos de socialización (Maccoby, 1992). Es por eso que juega un papel muy importante en la prevención e intervención en el consumo de drogas, tanto a la hora de inducir el riesgo como a la de promover la protección y la resiliencia (Velleman, Templeton y Copello, 2005). Sin embargo, la familia no sólo influye entre sus miembros sino que recibe al mismo tiempo la influencia de otros sistemas más amplios (Guilbert y Torres, 2001), por lo que estamos hablando de un sistema en continuo cambio, que se ve influido por múltiples factores como los cambios sociales, económicos y escolares que han hecho que el concepto de familia haya cambiado mucho en los últimos años. Así, se ha pasado de las familias tradicionales con ambos padres biológicos o familias extensas (convivencia con abuelos, tíos, primos...) a familias monoparentales (debido al divorcio o muerte de uno de los progenitores), familias reconstituidas (en convivencia con la nueva pareja de uno de los padres) e incluso a familias con padres del mismo sexo.

Dentro de la familia se producen una serie de interacciones sociales que influyen en el curso del desarrollo psicológico de la persona (Arranz, 2004; Justicia y Cantón, 2011). Pero, ¿Qué ocurre cuando hay problemas dentro de la familia? En esta revisión nos planteamos analizar la relación entre la desorganización familiar y el consumo de sustancias psicoactivas. Sin embargo, nos encontramos con que el concepto de desorganización familiar es muy amplio, y aunque se ha intentado clarificarlo y conceptualizarlo en distintas ocasiones, todavía su definición es ambigua y poco clara.

Siguiendo un orden cronológico, Locke (1940) consideraba la desorganización familiar como resultado de la movilidad de la familia y, en concreto, establecía cuatro posibilidades: la desorganización familiar como consecuencia de un alto grado de movilidad entre los distintos miembros de la familia, de cambiarse a una comunidad extraña, cambiar de clase social o separación espacial de alguno de sus miembros. Unos años después, Komarovsky y Willard (1945) establecian en un estudio sociológico de la familia, que el divorcio era una forma de desorganización familiar, así como la muerte de uno de los padres y la emancipación de los hijos. Por su parte, Coulter (1948) amplía el concepto y especifica que todas las familias pasan por los procesos de organización, desorganización y reorganización pero en un menor grado, siendo las familias desorganizadas aquellas en las que todo ello lleva a no poder funcionar de modo normal. Geismar, Lasorte y Ayres (1962) inciden en la misma dirección señalando que la desorganización familiar se estudia tradicionalmente teniendo en cuenta determinadas conductas como divorcio, separación, delitos, delincuencia juvenil y negligencia, entre otras. Este mismo grupo investigador, Geismar y LaSorte (1963), trató de descubrir qué factores estaban asociados con la desorganización familiar. Concluyen que la ausencia de expectativas realistas y una planificación para el futuro es más característico de familias problemáticas que de familias estables. Además, suele haber más diferencia de edad entre el hombre y la mujer, más conflictos durante el periodo para llegar a conocerse, más embarazos prematrimoniales, menos matrimonios por la iglesia y más expectativas irrealistas sobre la vida
$\mathrm{T}$ he family constitutes a key component in human development, being one of the first elements of socialization (Maccoby, 1992). Hence its crucial role in drug-use prevention and intervention, as regards both increased risk and, on the other hand, the promotion of protection and resilience (Velleman, Templeton, \& Copello, 2005). However, not only does the family influence its members, it is itself influenced by other, more extensive systems (Guilbert \& Torres, 2001), so that we are talking about a system that is constantly changing, under the influence of multiple factors such as social, economic and educational changes; indeed, such factors have meant that the concept of the family has changed a great deal in recent years. Thus, the predominance of the traditional family with both biological parents and the extended family (sharing the home with grandparents, uncles, cousins, etc.) has been diluted through the emergence of one-parent families (as a result of divorce or death), reconstituted families (involving the new partner of one of the biological parents), and even families with same-sex parents.

Within the family there occur a series of social interactions that influence the person's psychological development (Arranz, 2004; Justicia \& Cantón, 2011), but what happens when there are problems within the family? In this review we set out to analyze the relation between family disorganization and the use of psychoactive substances. However, we find that the concept of family disorganization is a very broad one, and that its definition, despite numerous attempts to clarify it, remains ambiguous and unclear.

To follow a chronological order, Locke (1940) considered family disorganization to be the result of family mobility, and identified four specific possibilities: family disorganization as a consequence of a high degree of mobility among the different family members, of moving to a new and strange community, of changing social class or of the spatial separation of one or more of its members. A few years later, Komarovsky and Willard (1945), in a sociological study of the family, concluded that divorce was a form of family disorganization, as well as the death of a parent and the emancipation of the children. Later, Coulter (1948) broadened the concept, arguing that all families go through processes of organization, disorganization and reorganization, but to a lesser degree, disorganized families being those in which such processes lead to a disruption of their normal functioning. Geismar, La Sorte and Ayres's (1962) work was in the same line, identifying behaviours traditionally studied in relation to family disorganization, such as divorce, separation, crime, juvenile delinquency or neglect. Members of this same research group, Geismar and La Sorte (1963), attempted to discover which factors were associated with family disorganization. They concluded that a lack of realistic expectations and planning for the future is more characteristic of problem families than of stable families. Also, there tends to be less age difference between the man and the woman, more conflicts during the period of courtship, more pre-marital pregnancies, fewer church 
marital. Además, las deudas financieras eran más comunes en las familias con un funcionamiento pobre, menor satisfacción durante el primer año como familia, la sobrevaloración del sexo (que no se relacionó con una satisfacción general en el matrimonio o un interés en los hijos) y, finalmente, una menor planificación relacionada con el tener hijos. Además, en las familias desorganizadas había una tendencia por parte del padre (no en la madre) de haber estado casado dos o más veces y muchos más padres de familias inestables procedian de hogares en los que los padres habían experimentado una separación temporal o permanente.

En esta misma línea, Sprey (1966) indicó que la desorganización familiar tiende a ser un "cajón de sastre" que engloba todas las características no deseables relacionadas con la familia como pueden ser el adulterio, el divorcio, la ilegitimidad, etc. Más tarde, Carman (1981) señalaba que la desorganización familiar podía ser entendida como una experiencia directa de problemas de la vida en el hogar, desventajas socioeconómicas $u$ otros problemas en la vida familiar.

Ya en la década de los 90, Caton et al. (1994) incluyeron dentro de la desorganización familiar variables como: baja constancia en la crianza, baja estabilidad en la residencia, ingresos inadecuados, dependencia de la asistencia pública, violencia familiar, enfermedad mental, abuso de sustancias o criminalidad en uno de los padres. Por su parte, Zucker, Davies, Kincaid, Fitzgerald y Reider (1997) consideraron que la desorganización familiar se producía en función de la violencia familiar y el número de separaciones maritales que se habian producido desde que los miembros de la pareja estaban juntos. Guilbert y Torres (2001) incluyen dentro de la desorganización familiar la falta de consenso entre normas, sentimientos de falta de comunicación y hostilidad entre sus miembros, riñas familiares continuas, parejas en permanente desacuerdo, disputas con agresión física o psicológica, familias destruidas por el abandono de alguno de los padres, sentimientos de rechazo, cogniciones familiares disfuncionales y presencia frecuente de sentimientos de desesperanza y pesimismo en ambos padres acompañados de actitudes y conductas pasivas ante su propia vida y familia. Para Hussong y Chassin (2002) la desorganización familiar implicaba hasta qué punto las familias seguian un horario regular y rutinas, tenían dificultades para hacer planes debido a la interferencia de acontecimientos inesperados y podian contar con el cumplimiento de promesas por parte de los miembros de la familia.

Tyler (2006) entendía la desorganización familiar como la presencia de abuso de sustancias de los padres o problemas de salud mental y Yabiku et al. (2007a) consideraban que habia desorganización social en la familia cuando estaba presente sólo uno de los padres.

Finalmente, para dificultar más la definición de desorganización familiar encontramos el término disrupción familiar, muy cercano al concepto de desorganización familiar, empleado por Carlson, Egeland y Sroufe (2009). Este término era empleado para referirse al nivel de estabilidad o disrupción en la composición de los miembros de la familia basándose en el número de parejas románticas de la madre, número de compañeros de la madre que vivian en casa, weddings, and more unrealistic expectations about married life. Moreover, financial debt was more common in families with poor functioning, as well as less satisfaction during the first year as a family, an overvaluing of sex (which was not related to general satisfaction in the marriage or interest in the children), and finally, less planning related to having children. There was also a tendency in disorganized families for the father (not the mother) to have been married twice or more, and many parents of unstable families came from homes in which their own parents had been temporarily or permanently separated.

In this same line, Sprey (1966) pointed out that family disorganization tends to be a kind of "ragbag" or miscellaneous category that accommodates all undesirable characteristics related to the family - adultery, divorce, illegitimacy, and so on. Later, Carman (1981) would suggest that family disorganization could be understood as a direct experience of life problems in the home, socio-economic disadvantage or other problems of family life.

By the 1990s, Caton et al. (1994) were including within family disorganization variables such as low levels of constancy in child rearing, low stability of residence, inadequate earnings, dependence on public benefits, family violence, mental illness, substance abuse or criminality of one of the parents. For their part, Zucker, Davies, Kincaid, Fitzgerald and Reider (1997) considered family disorganization to arise as a result of family violence and the number of marital separations that had occurred since the couple first got together. Guilbert and Torres (2001) include within family disorganization the following factors: lack of consensus over norms, feelings of lack of communication and hostility among family members, constant arguing in the family, couples continually disagreeing, disputes with physical or psychological aggression, families destroyed through one parent leaving, feelings of rejection, dysfunctional family cognitions, and frequent presence of feelings of desperation and pessimism in both parents accompanied by passive attitudes and behaviours toward their own lives and toward the family. For Hussong and Chassin (2002), family disorganization depended on the extent to which families did or did not follow regular timetables and routines and had difficulties for making plans due to the interference of unexpected events, and their members were able to keep promises to one another.

Tyler (2006) understood family disorganization as the presence of substance abuse in the parents or mental health problems, and Yabiku, Dixon, Okamoto, Marsiglia and Kulis (2007) considered there to be social disorganization in the family when only one of the parents was present.

Finally, to complicate the definition of family disorganization even more, we find the term family disruption, very close to the concept of family disorganization, and employed by Carlson, Egeland and Sroufe (2009). This term was used to refer to the level of stability or disruption in the composition of the family based 
número de entradas y salidas de la casa de los compañeros de la madre y el cambio de domicilio realizado por la madre y el niño.

De todos los estudios que hemos comentado anteriormente se puede extraer la conclusión de que la desorganización familiar no ha sido operacionalizada ni conceptualizada hasta el momento. En esta revisión, y basándonos en todo lo anterior, entenderemos por desorganización familiar a aquellas familias en las que alguno de los padres presente una psicopatología o enfermedad mental (Caton et al., 1994; Coulter, 1948; Geismar, Lasorte y Ayres, 1962; González, 2000; Herrera y Avilés, 2000; Tyler, 2006), haya un solo padre (familias monoparentales) debido al divorcio o muerte $u$ otras circunstancias de alguno de los padres (Carlson et al., 2009; Carman, 1981; Coulter, 1948; Geismar et al., 1962; González, 2000; Guilbert y Torres, 2001; Herrera y Avilés, 2000; Komarovsky y Willard, 1945; Locke, 1940; Sprey, 1966; Yabiku, Dixon et al., 2007; Zucker et al., 1997) o que los padres sean consumidores de sustancias (Caton et al., 1994; Coulter, 1948; Herrera y Avilés, 2000; Tyler, 2006).

Hasta ahora han sido muchos los estudios que se han centrado en estudiar la relación entre ciertas variables familiares y el consumo de drogas (Nunes-Costa, Lamela y Figueiredo, 2009; Petraitis, Flay, Miller, Torpy y Greiner, 1998; Velleman et al., 2005), sin embargo, pocos han sido los que se centraron en el estudio de la desorganización familiar y el consumo de drogas legales e ilegales. Teniendo esto en cuenta, el objetivo de esta revisión es analizar los estudios empiricos llevados a cabo sobre la relación entre desorganización familiar y el consumo de drogas, tanto legales como ilegales de los hijos en los últimos 30 años (1980-2010). on number of mother's intimate partners, number of mother's partners who lived in the house, number of entries and exits of mother's partners and change of residence made by the mother and the child.

On the basis of all the studies mentioned, we can conclude that family disorganization has so far not been operationalized or conceptualized. In this review, and based on the previous research, we shall understand by family disorganization those families in which one of the parents presents a psychopathology or mental illness (Caton et al., 1994; Coulter, 1948; Geismar et al., 1962; González, 2000; Herrera \& Avilés, 2000; Tyler, 2006), there is a single parent (one-parent families) due to divorce, death or other circumstances of one of the parents (Carlson et al., 2009; Carman, 1981; Coulter, 1948; Geismar et al., 1962; González, 2000; Guilbert \& Torres, 2001; Herrera \& Avilés, 2000; Komarovsky \& Willard, 1945; Locke, 1940; Sprey, 1966; Yabiku, Dixon et al., 2007; Zucker et al., 1997), or the parents are substance users (Caton et al., 1994; Coulter, 1948; Herrera \& Avilés, 2000; Tyler, 2006).

To date, many studies have explored the relation between certain family variables and drug use (Nunes-Costa, Lamela, \& Figueiredo, 2009; Petraitis, Flay, Miller, Torpy, \& Greiner, 1998; Velleman et al., 2005). However, few have focused on family disorganization and the use of legal and illegal drugs. With this in mind, the aim of this review is to analyze the empirical studies carried out in the last 30 years (1980-2010) on the relation between family disorganization and the drug use, both legal and illegal, of offspring.

\section{Método}

Para la realización de la presente revisión se utilizaron las bases de datos de PubMed y PsycINFO empleando el término de búsqueda "family disorganization" junto con otros conceptos que se podrian englobar dentro de la definición de desorganización familiar, como hemos señalado en el apartado introductorio, con el objetivo de profundizar en el tema y evitar así la pérdida de información que podría ser relevante. Los términos empleados junto con el de "family disorganization" fueron los siguientes: "divorce and drugs", "marital disorganization", "family structure", "separation", "divorce", "single parent families", "alcoholic parents", "drug-addicted parents", "parents with mental disorder", "children with drug, alcohol, and mental health problems", "family dissolution", "marital maladjustment", "family desintegration", "maladjusted family", "family disorder", "family and poor", "family and war", "remarriage", "multiproblem families", "children of alcoholics", "children of drug users", "family disruption" y "parents psychopathology". Todos estos términos fueron combinados con: "substance abuse disorders", "addiction", "drug abuse", "drug use", "drug dependence", "alcohol", "alcohol dependence", "beer", "wine", "spirits", "hard liquor", "smoking", "tobacco", "cigarettes", "illicit drug", "narcotics", "morphine", "cannabis", "hashish", "marijuana", "heroin", "heroin

\section{Method}

The databases used were PubMed and PsycINFO, and the search term was "family disorganization" together with others referring to concepts that could be included in the definition of family disorganization, as mentioned in the introduction, with the aim of exploring the issue in more depth and avoiding the loss of potentially relevant information. The search terms used together with "family disorganization" were: "divorce and drugs", "marital disorganization", "family structure", "separation", "divorce", "single-parent families", "alcoholic parents", "drug-addicted parents", "parents with mental disorder", "children with drug, alcohol, and mental health problems", "family dissolution", "marital maladjustment", "family disintegration", "maladjusted family", "family disorder", "family and poor", "family and war", "remarriage", "multiproblem families", "children of alcoholics", "children of drug users", "family disruption" and "parent's psychopathology". All of these terms were combined with: "substance abuse disorders", "addiction", "drug abuse", "drug use", "drug dependence", "alcohol", "alcohol dependence", "beer", "wine", "spirits", "hard liquor", "smoking", "tobacco", "cigarettes", "illicit drug", "narcotics", "morphine", "cannabis", "hashish", "marijuana", 
dependence", "ecstasy", "MDMA", "psychodelic agent", "hallucinogens", "cocaine", "crack cocaine", "lysergic acid", "LSD", "designer drugs" y "club drugs".

Se limitó la búsqueda a los estudios publicados entre el 1 de enero de 1980 y el 31 de diciembre de 2010, así como por el idioma de los mismos, incluyendo aquellos trabajos escritos en inglés, español, francés, italiano y portugués. Únicamente se tuvieron en cuenta aquellos artículos empíricos que contuviesen datos de estudios originales.

Los resultados de la búsqueda indicaron que en la base de datos de PubMed y Psyclnfo hay un total de 290 referencias sobre el tema. Tras el control de duplicados en ambas bases de datos y tras la lectura de los abstracts, se seleccionaron un total de 71 artículos empíricos que se incluyen en la presente revisión (Figura 1). "heroin", "heroin dependence", "ecstasy", "MDMA", "psychodelic agent", "hallucinogens", "cocaine", "crack cocaine", "lysergic acid", "LSD", "designer drugs" and "club drugs".

The search was restricted to studies published between 1st January 1980 and 31st of December 2010, as well as by their languages, only those in English, Spanish, French, Italian and Portuguese being included. Furthermore, we considered only empirical articles based on original data.

The results of the search indicated that the PubMed and Psyclnfo databases included a total of 290 references on the issue. After controlling for duplicates in both databases, and having read the abstracts, a total of 71 empirical articles were included in the present review (Figure 1).

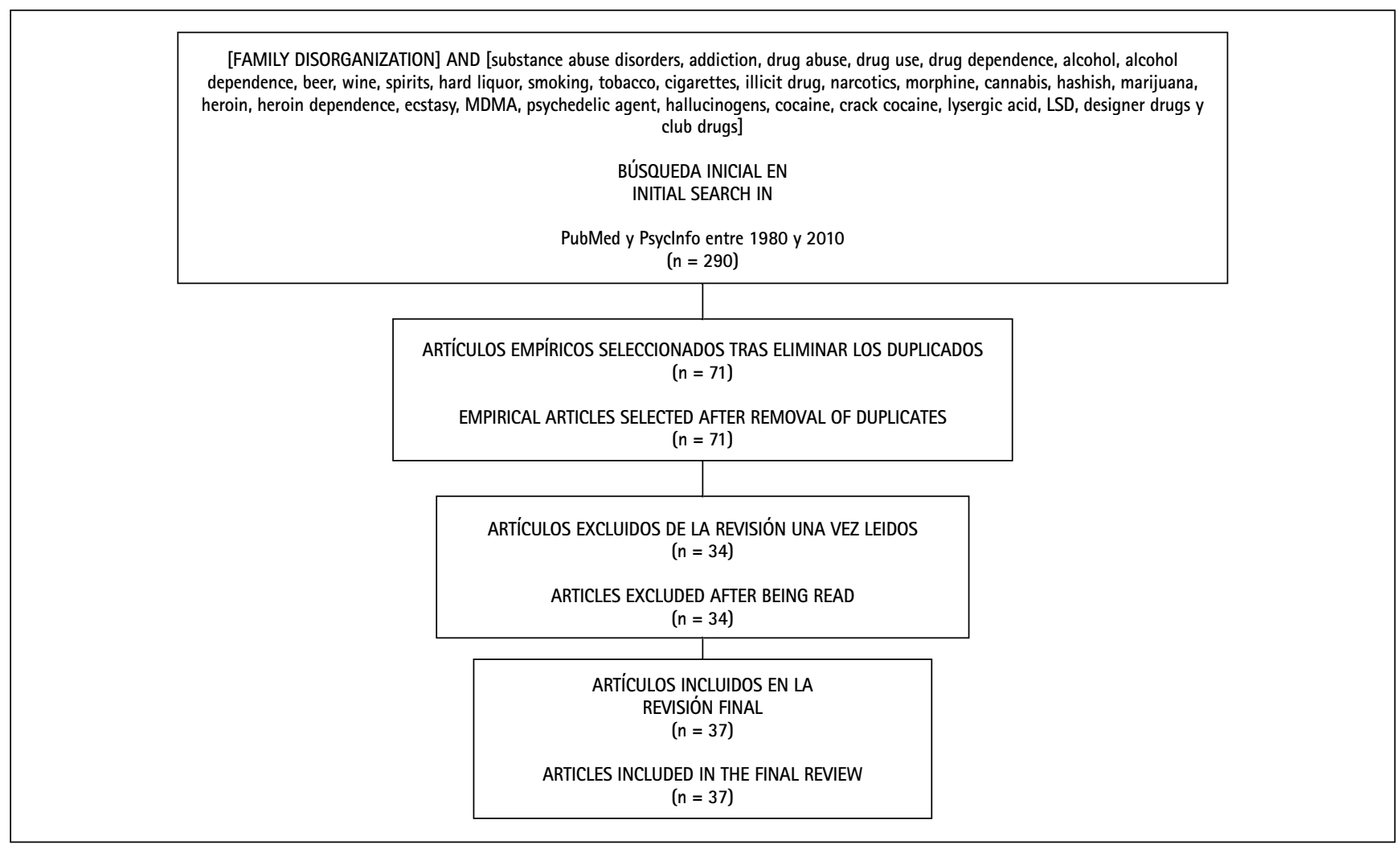

Figura 1. Metodología para la selección de los estudios

Figure 1. Methodology for selection of the studies

\section{Resultados}

Una vez leídos los 71 artículos encontrados en las bases de datos de PubMed y PsycINFO, 34 fueron excluidos por no estar relacionados con la temática de la revisión. De este modo, en la revisión final se incluyeron 37 artículos empíricos.

Para una mejor compresión de los resultados encontrados hemos dividido en tres apartados toda la información analizada en función de las tres variables que hemos considerado más relevantes para definir la desorganización familiar, que serian: padres consumidores de sustancias, estructura familiar no intacta y psicopatología de los padres.

\section{Results}

After all 71 articles from the PubMed and PsycINFO databases had been read, 34 were excluded because they were unrelated to the subject of the review. Thus, the final review covered 37 empirical articles.

For a better understanding of the results, we have divided the information analyzed into three sections, in accordance with the three variables we considered most relevant for defining family disorganization: substance-user parents, non-intact family structure and parents' psychopathology. 


\section{Padres consumidores de sustancias y consumo de drogas de los hijos}

Los estudios revisados indican que el consumo de alcohol y drogas de los padres influye en el consumo de estas sustancias en los hijos. En concreto, Mio, Nanjundappa, Verleur y de Rios (1986) analizaron el abuso de sustancias en una muestra de adolescentes delincuentes sexuales y encontraron que todos los jóvenes eran consumidores de drogas y admitian que sus familiares también lo eran. Neisen (1993) también encontró que el abuso de drogas por parte de los padres era uno de los mejores predictores del consumo de drogas por vía parenteral en una muestra de varones homosexuales.

En el caso concreto del alcohol, Brown y Rinelli (2010) señalaron que el consumo de alcohol por parte de la madre (no se evaluaba el consumo de alcohol del padre) estaba asociado positivamente al consumo de alcohol del hijo. Además, se sabe que los jóvenes con padres alcohólicos experimentan menos organización familiar durante la adolescencia (seguir un horario regular, dificultades para hacer planes debido a la interferencia de acontecimientos inesperados y mantenimiento de promesas), lo que les lleva a un mayor comportamiento de riesgo debido a que manifiestan más síntomas internalizantes y externalizantes (Hussong y Chassin, 2002), así como un consumo de alcohol y drogas más temprano y frecuente en comparación con sus iguales que no tienen padres alcohólicos (Byran y Fly, 1984; Hussong, Bauer y Chassin, 2008; Hussong y Chassin, 2002; Hussong, Curran y Chassin, 1998; Ritter, Stewart, Bernet, Coe y Brown, 2002; Thompson, Lizardi, Keyes y Hasin, 2008; Weintraub, 1990). Weintraub (1990) planteó que esto podía ser debido a que en el funcionamiento familiar en estas familias con un padre alcohólico los niveles de conflicto y desorganización son elevados mientras que los niveles de calor y cohesión familiar son bajos. Habib et al. (2010) indicaron que una relación emocional entre padres e hijo adolescente cercana disminuye la probabilidad de que el hijo consuma alcohol si el padre no es consumidor de alcohol. Sin embargo, si la relación entre padre e hijo es cercana pero el padre es consumidor de alcohol, el adolescente podría no beneficiarse de la relación aumentando así las probabilidades de que consuma esta sustancia.

Tan sólo hemos encontrado un estudio en el que una historia familiar de problemas con el consumo de alcohol no estuvo relacionada con la experiencia de consecuencias relacionadas con el alcohol (Turner, Larimer y Sarason, 2000).

Aunque son menos los estudios que se centraron en analizar la relación entre padres fumadores y el consumo de tabaco de sus hijos en los artículos relacionados con la desorganización familiar, se sabe que los adolescentes fumadores tienen más probabilidades de tener un padre o una madre fumadores (Brown y Rinelli, 2010; Griesbach, Amos y Currie, 2003; Otten, Engels, van de Ven y Bricker, 2007) y se ha indicado que existe una relación "dosis-respuesta", de modo que el riesgo de consumo de tabaco es mayor si son ambos padres los que fuman que si fuma uno solo (Otten et al., 2007).

Para finalizar este punto, es necesario señalar que Brown y Rinelli (2010) encontraron en su estudio con 13.282 jóvenes y sus madres, que el modelado del consumo de tabaco y

\section{Substance-user parents and children's drug use}

The studies reviewed indicate that parents' alcohol and drug use influences the use of these substances by their children. Specifically, Mio, Nanjundappa, Verleur and de Rios (1986), analyzing substance abuse in a sample of adolescent sex offenders, found that all the young people were drug users and admitted that their families also used drugs. Neisen (1993) also found parents' drug abuse to be one of the best predictors of parenteral-route drug use in a sample of homosexual males.

In the specific case of alcohol, Brown and Rinelli (2010) reported that alcohol use by the mother (father's alcohol use was not assessed) was positively associated with the child's alcohol use. Moreover, it is known that young people with alcoholic parents experience less family organization during adolescence (keeping to a regular timetable; difficulties for making plans due to the interference of unexpected events; keeping promises), which results in higher levels of risk behaviour due to their greater numbers of internalizing and externalizing symptoms (Hussong \& Chassin, 2002), as well as earlier and more frequent use of alcohol and drugs compared to their peers without alcoholic parents (Byram \& Fly, 1984; Hussong, Bauer, \& Chassin, 2008; Hussong \& Chassin, 2002; Hussong, Curran, \& Chassin, 1998; Ritter, Stewart, Bernet, Coe, \& Brown, 2002; Thompson, Lizardi, Keyes, \& Hasin, 2008; Weintraub, 1990). Weintraub (1990) suggested that this may be due to the fact that in the functioning of families with an alcoholic parent the levels of conflict and disorganization are high, whilst those of warmth and cohesion are low. Habib et al. (2010) indicated that a close emotional relation between parent and adolescent child reduces the probability of the child using alcohol if the father does not drink. However, if the relationship between father and child is close but the father uses alcohol, the adolescent may fail to benefit from the relationship, with a consequent increase in the likelihood of his or her using this substance.

We found only one study in which family history of alcohol-use problems was unrelated to the experience of alcohol-related consequences (Turner, Larimer, \& Sarason, 2000).

Although there are fewer studies that focus on analyzing the relation between parents who smoke and the use of tobacco in their children among the articles related to family disorganization, it is known that adolescent smokers are more likely to have a mother or father who smokes (Brown \& Rinelli, 2010; Griesbach, Amos, \& Currie, 2003; Otten, Engels, van de Ven, \& Bricker, 2007), and a "dose-response" relationship has been reported, so that the risk of smoking is greater if both parents smoke than if only one of them smokes (Otten et al., 2007).

To conclude this section we should mention the study of 13,282 young people and their mothers by Brown and 
alcohol por parte de la madre variaba de manera considerable en función de la estructura familiar. De manera especifica, señalaron que el $22 \%$ de las madres en familias intactas eran fumadoras mientras que en las familias en las que la madre biológica convivía con su pareja fuera del matrimonio el porcentaje ascendía al 55\% y encontraron que en las familias intactas era menos probable que los hijos fumaran.

\section{Estructura familiar y consumo de drogas de los hijos}

Los adolescentes que viven en hogares monoparentales 0 con padrastros tienen más probabilidades de consumir drogas en comparación con adolescentes que viven con sus dos padres (Amey y Albrecht, 1998; Broman, Li y Reckase, 2008; Choquet, Hassler, Morin, Falissard, y Chau, 2008; Hetherington, Bridges e Insabella, 1998; Hoffman, 2002; Hoffman y Johnson, 1998; Hollist y McBroom, 2006; Kierkus y Hewitt, 2009; Suh, Schütz y Johanson, 1996). En concreto, se ha indicado que los adolescentes que viven con ambos padres biológicos tienen menos probabilidades de consumir cigarrillos y de beber alcohol que aquellos que viven con un solo padre o en una familia reconstituida (Bjarnason, Anderson, Choquet, Elekes, Morgan y Rapinett, 2003; Bjarnason, Davidaviciene, Miller, Nociar, Pavlakis y Stergar, 2003; Brown y Rinelli, 2010; Byran y Fly, 1984; Choquet et al., 2008; Griesbach et al., 2003; Habib, Santoro, Kremer, Toumbourou, Leslie y Williams, 2010; Hoffman y Johnson, 1998; Hollist y McBroom, 2006; Jeynes, 2001; Kirby, 2002, 2006; Ledoux, Miller, Choquet y Plant, 2002; Miller, 1997; Otten et al., 2007; Thompson, Lizardi, Keyes y Masin, 2008; Wolfinger, 1998).

Por ejemplo, Brown y Rinelli (2010) emplearon datos del Estudio Nacional Longitudinal de la Salud Adolescente (Nacional Longitudinal Study of Adolescent Health; Add Health), que se llevó a cabo entre 1994 y 1995, realizando entrevistas a adolescentes y sus madres en sus casas. La muestra total estuvo formada por 13.282 personas. Los adolescentes que viven en familias con dos padres biológicos casados son los que menos probabilidades tienen de consumir tabaco, alcohol o ambas sustancias, mientras que los adolescentes que viven en familias reconstituidas que cohabitan muestran niveles excepcionalmente altos de consumo de alcohol, tabaco o ambos. Este estudio demuestra que no todas las familias con dos padres son iguales.

En relación con el consumo de marihuana, la estructura familiar influye en el consumo de esta sustancia, de modo que los jóvenes con padres divorciados tienen más probabilidades de consumir marihuana (Hoffman, 1994). Chedid, Romo y Chagnard (2009) Ilevaron a cabo un estudio con 18 adolescentes con alto riesgo de consumo de cannabis y señalaron que el $75 \%$ de los adolescentes que vivian en familias reconstituidas presentaban dependencia del cannabis. En esta misma línea, otros estudios señalan que el consumo de cannabis es mayor en familias reconstituidas o monoparentales que en familias intactas (Choquet et al. 2008; Hemovich y Crano, 2009; Hoffman y Johnson, 1998; Hollist y McBroom, 2006; Jeynes, 2002; Ledoux et al., 2002). Hollist y McBroom (2006) estudiaron en una muestra de 15.455 jóvenes de Montana (Estados Unidos)
Rinelli (2010), who found that the modelling of smoking and drinking by the mother varied considerably according to the family structure. Specifically, they reported that 22\% of mothers in intact families were smokers, whilst in families in which the biological mother lived with her partner outside of marriage the percentage rose to 55\%, and in intact families the children were less likely to smoke.

\section{Family structure and children's drug use}

Adolescents who live in one-parent homes or with stepparents are more likely to take drugs, by comparison with adolescents who live with both parents (Amey \& Albrecht, 1998; Broman, Li, \& Reckase, 2008; Choquet, Hassler, Morin, Falissard, \& Chau, 2008; Hetherington, Bridges, \& Insabella, 1998; Hoffman, 2002; Hoffman \& Johnson, 1998; Hollist \& McBroom, 2006; Kierkus \& Hewitt, 2009; Suh, Schütz, \& Johanson, 1996). Specifically, it has been reported that adolescents who live with both biological parents are less likely to smoke and drink alcohol than those who live with just one parent or in a reconstituted family (Bjarnason, Anderson, Choquet, Elekes, Morgan, \& Rapinett, 2003; Bjarnason, Davidaviciene, Miller, Nociar, Pavlakis, \& Stergar, 2003; Brown \& Rinelli, 2010; Byram \& Fly, 1984; Choquet et al., 2008; Griesbach et al., 2003; Habib et al., 2010; Hoffman \& Johnson, 1998; Hollist \& McBroom, 2006; Jeynes, 2001; Kirby, 2002, 2006; Ledoux, Miller, Choquet, \& Plant, 2002; Miller, 1997; Otten et al., 2007; Thompson et al., 2008; Wolfinger, 1998).

For example, Brown and Rinelli (2010) used data from the National Longitudinal Study of Adolescent Health; Add Health), carried out between 1994 and 1995, interviewing adolescents and their mothers at home. The total sample was made up of 13,282 people. Adolescents living in families with two married biological parents are those with least probability of smoking, using alcohol, or both, whilst adolescents living in reconstituted families in which the partners are cohabiting show exceptionally high levels of drinking, smoking, or both. This study shows that not all families with two parents are the same.

As regards the use of marijuana, family structure has an influence, so that youngsters with divorced parents are more likely to consume this drug (Hoffman, 1994). Chedid, Romo and Chagnard (2009) carried out a study with 18 adolescents with high risk use of cannabis and they reported that $75 \%$ of adolescents of the sample living in reconstituted families were dependent on cannabis. In the same line, other studies indicate that cannabis use is greater in reconstituted or oneparent families than in intact families (Choquet et al., 2008; Hemovich \& Crano, 2009; Hoffman \& Johnson, 1998; Hollist \& McBroom, 2006; Jeynes, 2002; Ledoux et al., 2002). Hollist and McBroom (2006) studied in a sample of 15,455 young people from Montana (USA) the role of family structure and tension within the family unit in marijuana use. The main finding of this study was that, regardless of the conflict level 
el papel que jugaba la estructura familiar y la tensión dentro de la unidad familiar en su consumo de marihuana. El principal hallazgo de este estudio fue que, independientemente del nivel de conflicto en casa, los hijos que vivían con ambos padres tenían menos probabilidades de consumir marihuana.

En cuanto al consumo de otras drogas ilegales, los resultados apuntan en la misma dirección: los adolescentes de familias reconstituidas o monoparentales tienen más probabilidades de consumir drogas ilegales (Hemovich y Crano, 2009; Hoffman y Johnson, 1998; Miller, 1997) y, además, Neissen (1993) encontró que el divorcio o separación incrementa un $27 \%$ la probabilidad de consumo de drogas por vía parenteral en los hijos. Sólo hemos encontrado un estudio (Wagner, Ritt-Olson, Soto y Unger, 2008) en el que se concluía que los jóvenes que viven en familias monoparentales no tienen más probabilidades de consumir drogas.

Por otra parte, Habib et al. (2010) encontraron en un estudio sobre gestión y estructura familiar que la estructura familiar no era predictor significativo del consumo intensivo de alcohol de los hijos, mientras que la cercanía emocional con el padre y un buen manejo de la familia (establecimiento de reglas sobre el consumo de alcohol y salidas los fines de semana) sí lo eran.

Por último, dos estudios, que a diferencia de los anteriores que empleaban a jóvenes estudiantes o de la población general, emplean muestras de jóvenes delincuentes sexuales y consumidores de inhalantes. En uno, Mio et al. (1986) analizaron en siete varones adolescentes delincuentes sexuales el consumo de sustancias. Estos autores encontraron que todos eran consumidores de drogas y que sólo uno de ellos pertenecía a una familia intacta, mientras que en los demás casos los padres estaban divorciados o separados. Por otra parte, Jansen, Richter, Griesel y Joubert (1990) analizaron distintos factores sociales en 22 niños que habían consumido pegamento por vía intranasal. Los resultados del estudio señalaron que en el 64\% de los casos la familia había sufrido la muerte o abandono de uno de los padres (normalmente el padre) y habían introducido un padrastro que trataba mal al niño o lo rechazaba completamente. Si bien, hay que notar que en estos dos estudios las muestras son pequeñas y ello exige una replicación con muestras mayores para comprobar si se obtienen los mismos resultados.

\section{Psicopatología de los padres y consumo de drogas de los hijos}

En relación con la psicopatología de los padres, Weintraub (1990) siguió a 474 niños durante 10 años y encontró que el conflicto y la desorganización familiar alcanzaban niveles altos en familias en las que había un padre alcohólico, pero resalta que estos niveles aumentaban en aquellas familias en las que el padre alcohólico presentaba, además, un trastorno psiquiátrico. En dichas familias los jóvenes tenían más probabilidades de consumir sustancias. Por su parte, Neff (1994) analizó una muestra de 1.784 personas y encontró que en las mujeres de la muestra que tenían padres con una enfermedad mental presentaban mayores niveles de depresión, ansiedad, somatización y de consumo de alcohol en comparación con el grupo de padres sin trastorno mental. También Caton et al. (1994) encontraron at home, children living with both parents were less likely to use marijuana.

As far as the use of other illegal drugs is concerned, the results point in the same direction: adolescents in reconstituted or one-parent families are more likely to use illegal drugs (Hemovich \& Crano, 2009; Hoffman \& Johnson, 1998; Miller, 1997); moreover, Neisen (1993) found that divorce or separation increased by $27 \%$ the probability of parenteral-route drug use in the couple's offspring. We found only one study (Wagner, Ritt-Olson, Soto, \& Unger, 2008) that concluded that young people living in one-parent families were not more likely to use drugs.

At the same time, Habib et al. (2010) found in a study on family management and structure that family structure was not a significant predictor of intensive alcohol use in offspring, whilst emotional closeness to the father and good family management (setting down of rules about alcohol use and going out at weekends) were indeed significant predictors.

Finally, let us consider two studies which used samples of juvenile sex offenders and inhalant abusers - as opposed to those whose samples were made up of students or youngsters from the general population. In the first of these, Mio et al. (1986) analyzed substance use in seven male adolescent sex offenders. These authors found that all were drug users, and that just one of them came from an intact family, the parents of all the others being divorced or separated. In the second study, Jansen, Richter, Griesel and Joubert (1990) analyzed different social factors in 22 children who had sniffed glue. The results showed that in 64\% of cases one of the parents (normally the father) had died or left, and had been replaced by a step-parent who treated the child badly or rejected the child completely. Even so, it should be borne in mind that in these two studies the samples were small, so that they need to be replicated with larger samples to check whether the same results are obtained.

\section{Parents' psychopathology and children's drug use}

As regards parents' psychopathology, Weintraub (1990) followed up 474 children for 10 years and found that family conflict and disorganization attained high levels in families in which there was an alcoholic parent, but highlighted the fact that such levels were higher in those families in which the alcoholic parent also presented a psychiatric disorder. In such families, young people were more likely to use substances. Later, Neff (1994) analyzed a sample of 1,784 people and found that the women whose parents had a mental illness showed higher levels of depression, anxiety, somatization and alcohol use compared to those from parents without mental illness. Similarly, Caton et al. (1994) found in a sample of 200 males with schizophrenia that those with mentally ill parents 
en una muestra de 200 varones con esquizofrenia que aquellos que tenían padres con enfermedad mental no tenían un hogar en el que vivir, en comparación con los que tenían una vivienda, y además presentaban un mayor consumo de sustancias.

\section{Discusión}

Hemos revisado 37 investigaciones empíricas publicadas en los últimos 30 años (1980-2010) sobre la relación entre desorganización familiar y el consumo de sustancias de los hijos. Casi todos los estudios analizados coinciden en resaltar la importancia del consumo de sustancias por parte de los padres, la estructura familiar y la psicopatología en relación con el consumo de sustancias legales e ilegales de sus hijos. Sin embargo, en esta revisión nos hemos encontrado con una notable sobrevaloración de la estructura familiar sobre las otras dos características que componen lo que entendemos por desorganización familiar (psicopatología y consumo de drogas de alguno de los progenitores). Esto es debido sin duda al considerable aumento del número de divorcios que se han ido produciendo en los últimos años. Sin embargo, llegados a este punto debemos preguntarnos si una estructura familiar no tradicional (sin ambos padres biológicos) es igual a desorganización familiar.

Broman et al. (2008) propusieron que la relación entre consumo de drogas de los hijos y estructura familiar estaría mediada por otras variables como la crianza, el consumo de drogas de los iguales, la religiosidad y los problemas en el vecindario. En relación con esto, Brown y Rinelli (2010) señalaron que el mayor consumo de alcohol y tabaco en jóvenes de familias monoparentales y familias reconstituidas se debía en parte a un apoyo y control más débil por parte de la madre, al consumo de alcohol y tabaco por parte de la madre y a problemas socioeconómicos más prevalentes en estas familias que en las intactas con ambos padres biológicos. También Habib et al. (2010) indicaron que la estructura familiar dejaba de ser significativa en la predicción del consumo de alcohol, pasando a ser la cercanía emocional con los padres y una buena gestión de la familia (establecimiento de reglas sobre el consumo de alcohol y salidas los fines de semana) los factores que mejor predecian el consumo intensivo de alcohol (binge drinking). Además, se ha demostrado que las mujeres muestran menos depresión y un menor bienestar psicológico dos años después del divorcio que aquellas que permanecen en matrimonios conflictivos (Hetherington et al., 1998). Los hijos en familias con padres no divorciados que son altamente conflictivas tienen más problemas de ajuste psicológico y autoestima que los de familias con padres divorciados o de bajo conflicto no divorciados (Amato y Keith, 1991; Amato, Loomis y Booth, 1995).

Cabe preguntarse si el divorcio es causa de la desorganización familiar o es esta última la que causa el divorcio. Tomori, Zalar, Kores Plesnicar, Ziherl y Stergar (2001) resaltaron la importancia del conflicto dentro de la familia y señalaron que el consumo de tabaco en la adolescencia se producía en mayor medida en ambientes en los que los conflictos familiares ocurren de manera frecuente y en los que hay una falta de apoyo emocional por parte de los padres. Hetherington et al. (1998) apuntaron que las relaciones familiares disfuncionales, como were more likely to be homeless, as well as presenting higher levels of substance use.

\section{Discussion}

We reviewed 37 empirical studies published over the last 30 years (1980-2010) on the relation between family disorganization and children's substance use. Almost all the studies analyzed highlight the important role of parents' drug use and psychopathology and of family structure for the use of legal and illegal drugs by their children. However, our review revealed a marked preponderance of the study of family structure with respect to the other two characteristics involved in what we understand as family disorganization (psychopathology and drug use in one or both parents). This is undoubtedly due to the considerable increase in the rate of divorce over recent years in the developed countries. However, at this point we should ask ourselves whether a non-traditional family structure (without both biological parents) is synonymous with family disorganization.

Broman et al. (2008) proposed that the relation between offspring's drug use and family structure would be mediated by other variables, such as upbringing, peers' drug use, religiosity and problematic neighbourhood. In relation to this, Brown and Rinelli (2010) found that greater alcohol use and drinking in young people from one-parent and reconstituted families was due in part to weaker support and control by the mother, mother's smoking and drinking, and the greater likelihood of socio-economic problems found in these families compared to intact families with both biological parents. Likewise, Habib et al. (2010) argued that family structure was not significant in the prediction of alcohol use, insofar as binge drinking was better predicted by the child's emotional closeness to the parents and good family management (setting down of rules about alcohol use and going out at weekends). Moreover, it has been shown that women who divorce show lower levels of depression and greater psychological well-being two years later than those who remain in conflictive marriages (Hetherington et al., 1998). Children in families with non-divorced parents that are highly conflictive have more problems of psychological adjustment and self-esteem than those in families where the parents are divorced, or not divorced but with low levels of conflict (Amato \& Keith, 1991; Amato, Loomis, \& Booth, 1995).

It is relevant to ask here whether divorce is a cause of family disorganization or vice versa. Tomori et al. (2001) highlighted the importance of conflict within the family, pointing out that smoking in adolescence is more likely in settings in which family conflict is more frequent, and in which there is a lack of emotional support from the parents. Hetherington et al. (1998) argued that dysfunctional family relations, such as conflict, negativity, lack of support and non-authoritative parenting practices, exacerbated the effects of divorce and remarriage on the children's adjustment. However, if the divorced parents 
el conflicto, negatividad, falta de apoyo y crianza no democrática, exacerbaban los efectos del divorcio y de volver a casarse en el ajuste de los hijos. Sin embargo, si los padres divorciados son democráticos y sus familias armoniosas, cálidas y cohesivas, las diferencias entre el ajuste del hijo en estas familias y en las de no divorciados son reducidas. Esto apoya los resultados que encontraron Becoña et al. (2012) en su revisión sobre estilos parentales y consumo de sustancias en la que concluyeron que un estilo de crianza democrático estaba relacionado con un menor consumo de sustancias en los hijos.

Kristjansson, Sigfusdottir, Allegrante y Helgason (2009) subrayaron la importancia del conflicto familiar a la hora de entender la relación entre divorcio y consumo de tabaco y alcohol de los adolescentes. Además, no debemos olvidar que las familias en las que uno o ambos padres tienen problemas con el alcohol tienen más probabilidades de acabar en divorcio o en conflictos familiares (Hetherington et al., 1998; Jeynes, 2001) y que la psicopatología está asociada a un mayor consumo de tabaco (Becoña y Míguez, 2004).

Hoffman (1995) apuntó que la ruptura familiar o la reconstitución son acontecimientos estresantes que pueden llevar a relaciones con iguales consumidores de drogas si los vínculos familiares son débiles, pero que puede evitarse si el afecto por parte de los padres sigue siendo fuerte. De hecho, se ha indicado que después de la disolución marital de matrimonios altamente conflictivos o volátiles, los hijos informan de sentimientos de alivio y menores niveles de estrés, depresión y ansiedad por lo que las dinámicas monoparentales se convierten en un ambiente preferible para el hijo y les lleva a un menor riesgo en el desarrollo de problemas emocionales o disfuncionales como puede ser el consumo de drogas (Hemovich y Crano, 2009). Por eso es necesario tener en cuenta el momento en que se produce el divorcio ya que parece que los adolescentes de más edad responden implicándose menos con su familia y buscando sistemas de apoyo fuera de casa porque tienen más libertad, mientras que en adolescentes jóvenes este tipo de ruptura con el contacto familiar no es tan prevalente (Hoffman, 1994).

En este sentido, Kirby (2002) indicó también que la separación de los padres está asociada con un incremento en el número de amigos fumadores, lo que aumenta la probabilidad de que el adolescente se inicie en el consumo de tabaco al igual que señalaron Hollist y McBroom (2006) en relación al consumo de marihuana. También Farrell y White (1998) señalaron que los jóvenes que viven en hogares sin ambos padres biológicos podrían tener una mayor influencia de iguales consumidores de drogas. Sin embargo, estos autores añaden que una relación padre-adolescente o madre-adolescente (en familias monoparentales) caracterizada por la calidez, la buena comunicación y resolución de problemas son más resistentes a la influencia de los iguales consumidores de drogas. De hecho, Eggert y Herting (1991) señalaron que vivir sólo con la madre descendía el consumo de drogas en los participantes de un programa de prevención de drogas. Esto mismo indicaban Choquet at al. (2008) afirmando que el control parental debe ser sistemático independientemente del tipo de estructura familiar. are authoritative and their families harmonious, warm and close, the differences between children's adjustment in these families and those with non-divorced parents are reduced. This is in support of the findings of Becoña et al. (2012) in their review of parental styles and substance use, from which they concluded that an authoritative parental style was related to less substance use in the offspring.

Kristjansson, Sigfusdottir, Allegrante and Helgason (2009) stressed the importance of family conflict for understanding the relation between divorce and adolescents' smoking and drinking. Moreover, it should not be overlooked that families in which one or both parents have drinking problems are more likely to be affected by divorce or family conflict (Hetherington et al., 1998; Jeynes, 2001), and that psychopathology is associated with more smoking (Becoña \& Míguez, 2004).

Hoffman (1995) noted that family break-up or reconstitution are stressful events that can lead to the children forming relationships with drug-user peers if the family bonds are weak, though such friendships are more likely to be avoided if there are still high levels of affection from the parents. In fact, it has been found that after the break-up of highly conflictive or volatile marriages, the children report feelings of relief and lower levels of stress, depression and anxiety, so that one-parent situations become a preferable context for the children, and lead to lower risk of developing emotional problems or dysfunctional behaviours, such as drug use (Hemovich \& Crano, 2009). It is therefore necessary to take into account the moment at which the divorce occurs, since it appears that older adolescents respond by reducing their involvement with the family and seeking support systems outside it because they have more freedom, whilst in younger adolescents this type of break with family contact is not so prevalent (Hoffman, 1994).

In this line, Kirby (2002) also found that parents' separation is associated with an increase in the number of friends who smoke, which in turn increases the probability of the adolescent starting to smoke - echoing Hollist and McBroom's (2006) finding in relation to marijuana use. Farrell and White (1998) also reported that young people living in homes without both biological parents may be more influenced by drug-user peers. However, these authors add that a father-adolescent or mother-adolescent relationship (in one-parent families) characterized by warmth, good communication and problem-solving make children more resistant to the influence of peers who use drugs, while Eggert and Herting (1991) found that living with the mother alone reduced drug use among those on a drug-prevention program. This was backed up by Choquet at al. (2008), who asserted that parental control must be systematic, regardless of the type of family structure.

One-parent families tend to have lower incomes than other types of family, and their greater economic deprivation makes parental supervision and support more difficult, thus 
Las familias monoparentales tienden a tener menores ingresos que otros tipos de familias y una mayor deprivación económica hace que la supervisión y el apoyo parental sean más difíciles, incrementando así la probabilidad de consumo de drogas (Hoffman y Johnson, 1998), lo que resulta en un incremento de la influencia del grupo de iguales y en la aceptación de las conductas desviadas como el consumo de alcohol o drogas (Yabiku, Dixon et al., 2007). Además, los hijos que viven en familias monoparentales sólo están expuestos a la conducta de uno de los padres, mientras que en las familias con ambos padres la conducta de uno de ellos podría ser magnificada o amortiguada por la conducta del otro (Otten et al., 2007). Por último, Yabiku, Kulis, Marsiglia, Lewin, Nieri y Hussaini (2007) encontraron que vivir en familias con madres solteras disminuía la efectividad de un programa para combatir el consumo de alcohol.

Si nos centramos en las familias reconstituidas, Wolfinger (1998) indicó que el hecho de que los padres vuelvan a casarse atenúa, en cierto modo, el impacto del divorcio en el consumo de alcohol. Sin embargo, sabemos que la reformación de la unidad familiar implica una serie de negociaciones complejas sobre el papel de cada uno de los miembros de la familia y sus relaciones. Esto puede causar tensión, especialmente si el hijo no reconoce la autoridad del nuevo padre, o si el nuevo padre es reacio a asumir la autoridad a la hora de hacer frente a problemas relacionados con su nuevo hijo. Además, si los jóvenes pasan el tiempo con dos familias diferentes podría producirse una falta de claridad o desacuerdo entre los dos hogares en ciertos aspectos importantes como el consumo de sustancias (Griesbach et al., 2003). Por último, señalar que en este tipo de familias la introducción de nuevos hermanos podria incrementar la probabilidad de iniciarse en el consumo de drogas en el caso de que estos hermanos consuman alguna sustancia (Kirby, 2006).

En conclusión, se puede decir que una familia no intacta no es sinónimo de familia desorganizada, si bien es cierto, que la disolución del matrimonio a menudo va ligada a conflictos familiares consecuencia en algunos casos de la psicopatología de uno o ambos padres 0 al consumo de sustancias, lo que en conjunto provoca tensiones dentro de la familia que se traducen en desorganización familiar y que a menudo se relaciona con el consumo de sustancias, legales e ilegales, de los hijos.

\section{Problemas metodológicos de los estudios revisados}

Una gran parte de los estudios realizados sobre la relación entre desorganización familiar y el consumo de drogas merecen una especial atención debido a los problemas metodológicos que hemos encontrado.

En primer lugar existe un problema importante relacionado con el concepto de desorganización familiar. En la mayoría de los estudios revisados faltaba una definición operativa de lo que se entendia por desorganización familiar (Jansen et al., 1990; Mio et al., 1986; Tyler, 2006; Weintraub, 1990; Zucker et al., 1997).

En segundo lugar, y derivado de lo anterior, encontramos que las estrategias de evaluación de la desorganización fami- increasing the probability of drug use (Hoffman \& Johnson, 1998); this, in turn, results in greater influence of the peer group and increased acceptance of deviant behaviour such as drinking and drug-taking (Yabiku, Dixon et al., 2007). Moreover, children who live in one-parent families are only exposed to the behaviour of one of the parents, whilst in families with both parents the behaviour of one of them may be magnified or offset by that of the other (Otten et al., 2007). Finally, Yabiku et al. (2007) found that living in families with single mothers reduced the effectiveness of a program for combating alcohol use.

If we focus on reconstituted families, Wolfinger (1998) argued that the fact of a parent remarrying attenuated to some extent the impact of the divorce on alcohol use. However, we know that reformation of the family unit involves a series of complex negotiations about the role of each member of the family and their relationships. This can cause tension, especially if the child does not recognize the authority of the new parent, or if the new parent is reluctant to assume authority when it comes to dealing with problems related to his or her new child. Moreover, youngsters' spending time with two different families may be affected by a lack of clarity or disagreement between the two homes as regards certain aspects such as substance use (Griesbach et al., 2003). Finally, it should be borne in mind that in these types of family the introduction of new siblings may increase the likelihood of the existing children starting drug use, in the case of these new arrivals being substance users themselves (Kirby, 2006).

In conclusion, it can be said that a non-intact family is not synonymous with a disorganized family, despite the fact that marriage break-up is associated with family conflicts that are sometimes the consequence of psychopathology in one or both parents or of parents' drug use, which alone or jointly cause tension and, in turn, family disorganization, and which are often related to the use of substances, both legal and illegal, by the children.

\section{Methodological problems of the studies reviewed}

A large part of the studies carried out on the relation between family disorganization and drug use merit particular attention due to the methodological problems we have encountered.

First of all, there is a substantial problem related to the concept of family disorganization. In the majority of studies reviewed there is no operational definition of what is understood by family disorganization (Jansen et al., 1990; Mio et al., 1986; Tyler, 2006; Weintraub, 1990; Zucker et al., 1997).

Secondly, and following from the previous point, we found assessment strategies for family disorganization to be rather imprecise and sometimes totally lacking. Even in the studies 
liar eran poco precisas y en ocasiones inexistentes. Incluso en los estudios en los que se consideraba la estructura familiar como medida de la desorganización familiar existian problemas en su evaluación. Como han apuntado Wu y Martinson (1993), la estructura familiar normalmente se considera una instantánea en la que la familia intacta es comparada con la familia no intacta. Sin embargo, la estructura familiar normalmente es más complicada, particularmente cuando nos encontramos con familias reconstituidas, familias extensas o familias en transición. Así, tener en cuenta si el matrimonio es intacto o no dice poco sobre las relaciones o sobre la calidad de la vida familiar (Amey y Albrecht, 1998) que es lo realmente importante en lo referente a la desorganización familiar. Por eso, cuando se evalúa la estructura familiar es esencial considerar cómo ocurrió la ruptura familiar (ej. muerte de uno de los padres, divorcio, etc.) ya que se ha comprobado que la muerte de uno de los padres tiene distintos efectos que el divorcio, a pesar de que en ambos casos el resultado sea una familia monoparental (Hoffman, 1995).

Por eso, distinguir únicamente entre familia intacta, monoparental o reconstituida es una simplificación. Además, en los últimos años se ha producido un considerable aumento de madres solteras que nunca estuvieron casadas y existe un gran número de niños cuyos padres se separan pero que nunca llegan a divorciarse (Jeynes, 2002), hecho que no se ha tenido en cuenta en los estudios revisados.

Otro punto débil presente en la mayoría de los estudios revisados es que no se ha comparado a familias monoparentales con familias reconstituidas. Los distintos estudios coinciden al señalar que en comparación con las familias intactas, el consumo de drogas es mayor en jóvenes que viven en familias monoparentales o reconstituidas pero no establece diferencias entre ambas, con la excepción de Brown y Rinelli (2010), y es algo que debería estudiarse. De hecho, Wolfinger (1998) señaló que a pesar de que la estructura familiar es más débil en familias reconstituidas que en familias monoparentales, el control parental debería ser mayor en las familias reconstituidas, ya que independientemente de las dinámicas familiares, un padrastro o madrastra proporcionan una segunda fuente de autoridad y disciplina, lo que debería repercutir en el menor consumo de sustancias de los jóvenes. Sin embargo, Brown y Rinelli (2010) encontraron que los jóvenes de familias intactas eran los que menos alcohol y tabaco consumían seguidos de los jóvenes de familias monoparentales y reconstituidas que estaban casadas $y$, por último, los que más tabaco y alcohol consumian eran los jóvenes de familias reconstituidas que no se habian casado.

Teniendo en cuenta todo esto, proponemos que a la hora de estudiar la desorganización familiar deberían tenerse en cuenta una serie de factores:

\section{- ¿Qué se entiende por desorganización familiar?}

- En caso de divorcio, tener en cuenta cuáles fueron los motivos: consumo de sustancias de uno de los padres, malos tratos, psicopatología de uno de los padres, etc., así como el tiempo transcurrido desde que se produjo y el grado de acuerdo entre los padres divorciados en lo referente a la educación del hijo. that considered family structure as a measure of family disorganization there were problems for its assessment. As pointed out by Wu and Martinson (1993), family structure is normally considered in terms of a "snapshot", whereby intact families are compared to broken families. However, family structure is normally more complicated, particularly in the cases of reconstituted families, extended families or families in transition. Thus, taking into account whether the marriage is intact or not says little about its relationships or about the quality of family life (Amey \& Albrecht, 1998), which is what is really important with regard to family disorganization. Therefore, on assessing family structure it is essential to consider how the family break-up occurred (death of a parent, divorce, etc.), since it has been clearly shown how the death of one of the parents has different effects from divorce, despite the fact that in either case the result is a one-parent family (Hoffman, 1995).

Therefore, distinguishing only between intact, oneparent and reconstituted families represents a simplification. Moreover, in recent years there has been a considerable increase in the numbers of single mothers who were never married, and there are many children whose parents separate but never actually divorce (Jeynes, 2002), and these aspects were not taken into account in the studies reviewed.

Another weak point present in the majority of the studies reviewed is that there is no comparison between one-parent families and reconstituted families. The different studies coincide in pointing out that compared to intact families, drug use is greater in youngsters living in one-parent or reconstituted families, but no differences are identified between the two, except by Brown and Rinelli (2010); this is an aspect that should be studied in future research. In fact, Wolfinger (1998) remarked that in spite of a weaker family structure in reconstituted families than in one-parent families, parental control should be greater in reconstituted families, since regardless of family dynamics, a stepmother or stepfather provides a second source of authority and discipline, which should translate into less substance use by the youngsters. However, Brown and Rinelli (2010) found that young people in intact families were those who drank and smoke least, followed by those in one-parent families and reconstituted families with remarriage, whilst those who drank and smoked most were those living in reconstituted families without remarriage.

Taking all of the above into account, we propose that research on family disorganization should consider a series of factors:

- The definition of family disorganization, what we understand by the term.

- In the case of divorce, the reasons for it - substance use by one of the parents, abuse or maltreatment, psychopathology in one of the parents, etc. - as well as the time elapsed since the divorce and the extent of agreement between the divorced parents with regard to the child's upbringing. 
- En caso de madres solteras, tener en cuenta si el hijo conoció o convivió alguna vez con el padre biológico o si tiene contacto con él.

- Presencia de miembros de familia extensa (abuelos, tíos, etc.).

- Posible influencia de los hermanos.

- Si se trata de una familia monoparental comprobar si existen diferencias en función de si está encabezada por una madre o un padre.

\section{Conclusiones}

Dada la relevancia del consumo de drogas, de los nuevos tipos de familias y de la interacción entre consumo de drogas, familia y otras variables mediadoras, realizar buenos estudios sobre esta cuestión favorecerá el mejor conocimiento sobre el tema y poder actuar más adecuadamente con las personas que tienen problemas con el consumo de drogas. De la presente revisión se pueden extraer las siguientes conclusiones:

1) La desorganización familiar todavía no ha sido suficientemente operacionalizada ni conceptualizada, por lo que sería necesario establecer una definición clara de qué se entiende por desorganización familiar.

2) Los estudios analizados resaltan la importancia de la familia, y de manera específica, del consumo de sustancias por parte de los padres, así como de la estructura familiar y la psicopatología en el consumo de sustancias legales e ilegales de los hijos.

3) Se ha observado una notable sobrevaloración de la estructura familiar sobre los otros componentes de la desorganización de la familia que influyen en el consumo de sustancias de los hijos (consumo de drogas y psicopatología de los padres). En este sentido, cabe preguntarse si el divorcio es causa de la desorganización familiar o es esta última la que causa el divorcio.

4) Es necesario mejorar las estrategias de evaluación de la desorganización familiar ya que las empleadas en los distintos estudios revisados eran poco precisas y en ocasiones inexistentes.

\section{Reconocimientos}

La preparación de este artículo ha sido financiado en parte por la European Commission, Directorate General for Justice, con fondos del proyecto European Family Empowerment (JLS/DPIP/2008-2/112). Subvencionado también por la Delegación del Gobierno para el Plan Nacional sobre Drogas según la Orden SPI/1129/2011, de 15 de abril, y Orden SPI/ 2379/2011, de 24 de agosto.

\section{Conflictos de interés}

No existen.
- In the case of single mothers, whether or not the child has ever met or lived with the biological father, or has contact with him.

- The presence of members of the extended family (grandparents, uncles/aunts, etc.).

- Possible influence of siblings.

- In the case of a one-parent family, whether or not there are differences depending on whether it is headed by a mother or a father.

\section{Conclusions}

Given the relevance of drug use, of the new types of family and of the interaction between drug use, family and other mediating variables, thorough and careful research on these issues is needed with a view to improving our knowledge of them and being able to intervene more appropriately with people experiencing drug-use problems. The following conclusions can be drawn from the present review:

1) Family disorganization has not yet been sufficiently operationalized or conceptualized, so that it is necessary to establish a clear definition of what is meant by the term.

2) The studies analyzed highlight the importance of the family, and specifically parents' substance use and psychopathology and family structure, for the use of legal and illegal substances by the children.

3) We observed a marked preponderance of family structure with respect to the other aspects involved in family disorganization that influence the children's substance use (parents' drug use and psychopathology). In this regard, we should consider whether divorce is a cause of family disorganization or vice versa.

4) It is necessary to improve assessment strategies for family disorganization, since in the studies reviewed they were found to be rather imprecise and sometimes totally lacking.

\section{Acknowledgements}

Work on this article was partially funded by the European Commission, Directorate General for Justice, with funds from the European Family Empowerment project (JLS/DPIP/20082/112). Funding also came from the Government Office for the Spanish National Plan on Drugs (Orden SPI/1129/2011, de 15 de abril, and Orden SPI/ 2379/2011, de 24 de agosto).

\section{Interest conflict}

None declared 


\section{Referencias}

Amey, C. H. y Albrecht, S. T. (1998). Race and ethnic differences in adolescent drug use: The impact of family structure and the quantity and quality of parental interaction. Journal of Drug Issues, 28, 283-298.

Arranz, E. (2004). El estudio del contexto familiar y el desarrollo psicológico. En E. Arranz, Familia y desarrollo psicológico (pp. 97-123). Madrid: Pearson Educación.

Amato, P. R. y Keith, B. (1991). Parental divorce and adult well-being of children: A meta-analysis. Journal of Marriage and the Family, 58, 356-365.

Amato, P. R., Loomis, L. S. y Brooth, A. (1995). Parental divorce, marital conflict, and offspring well-being during early adulthood. Social Forces, 73, 895-915.

Becoña, E., Martínez, U., Calafat, A., Juan, M., Fernández-Hermida, J. R. y Secades-Villa, R. (2011). Parental styles and drug use: A review. Drugs: Education, Prevention \& Policy 19, 1-10 . doi: 10.3109/09687637.2011.631060.

Becoña, E. y Míguez M. C. (2004). Consumo de tabaco y psicopatología asociada. Psicooncología, 1, 99-112.

Bjarnason, T., Anderson, B., Choquet, M., Elekes, Z., Morgan, M. y Rapinett, G. (2003). Alcohol culture, family structure and adolescent alcohol use: Multilevel modeling of frequency of heavy drinking among 15-16 year old students in 11 European countries. Journal of Studies on Alcohol, 64, 200-208.

Bjarnason, T., Davidaviciene, A. G., Miller, P., Nociar, A., Pavlakis, A. y Stergar, E. (2003). Family structure and adolescente cigarette smoking in eleven European countries. Addiction, 98, 815-824. doi: 10.1046/j.1360-0443.2003.00395.x.

Broman, C. L., Li, X. y Reckase, M. (2008). Family structure and mediators of adolescent drug use. Journal of Family Issues, 29, 1625-1649. doi: 10.1177/0192513X08322776.

Brown, S. L. y Rinelli, L. N. (2010). Family structure, family processes, and adolescent smoking and drinking. Journal of Research on Adolescence, 20, 259-273. doi: 10.1111/j.1532-7795.2010.00636.x.

Byram, O. W. y Fly, J. W. (1984). Family structure, race, and adolescents' alcohol use: A research note. The American Journal of Drug and Alcohol Abuse, 10, 467-478. doi: 10.3109/00952998409001484.

Carlson, E. A., Egeland, B. y Sroufe, L. A. (2009). A prospective investigation of the development of borderline personality symptoms. Development and Psychopathology, 21, 1131-1334. doi: 10.1017/s0954579409990174.

Carman, R. S. (1981). Family disorganization and problem drinking in a rural population. International Journal of Social Psychiatry, 27, 253-256. doi: 10.1177/002076408102700402.

Caton, C. L. M., Shrout, P. E., Eagle, P. F., Opler, L. A., Felix, A. y Dominguez, B. (1994). Risk factors for homelessness among schizophrenic men: A case-control study. American Journal of Public Health, 84, 265-270. doi: 10.2105/AJPH.84.2.265.

Chedid, M., Romo, L. y Chagnard, E. (2009). Consommation du cannabis chez les adolescents: liens entre structure, cohesion, hiérarchie familiales et niveau de consummation. Annales Médico Psychologiques, 167, 541-543. doi: 10.1016/j.amp.2009.06.012.

Choquet, M., Hassler, C., Morin, D., Falissard, B. y Chau, N. (2008). Perceived parenting styles and tobacco, alcohol and cannabis use among French adolescents: Gender and family structure differentials. Alcohol \& Alcoholism, 43, 73-80. doi: 10.1093/alcalc/ agm060.

Coulter, C. W. (1948). Family disorganization as a causal factor in delinquency and crime. Recuperado el 11 de abril de 2012 de http://heinonline.org/HOL/LandingPage?collection=journals\&han dle $=$ hein.journals/fedpro12\&div $=45 \& \mathrm{id}=\&$ page $=$

Eggert, L. L. y Herting, J. R. (1991). Preventing teenage drug abuse: Exploratory effects of network social support. Youth \& Society, 22, 482-524. doi: 10.1177/0044118X91022004004.

Farrell, A. D. y White, K. S. (1998). Peer influences and drug use among urban adolescents: Family structure and parent-adolescent relationship as protective factor. Journal of Consulting and Clinical Psychology, 66, 248-258. doi: 10.1037/0022-006X.66.2.248.

Geismar, L. L. y La Sorte, M. A. (1963). Factors associated with familiy disorganization. Marriage and Family Living, 25, 479-481.

Geismar, L. L., Lasorte, M. A. y Ayres, B. (1962). Measuring family disorganization. Marriage and Family Living, 24, 51-56. doi: $10.2307 / 348226$.

González, I. (2000). Las crisis familiares. Revista Cubana de Medicina General Integral, 16, 280-286.

Griesbach, D., Amos, A. y Currie, C. (2003). Adolescent smoking and family structure in Europe. Social Science \& Medicine, 56, 41-52. doi: 10.1016/S0277-9536(02)00014-X.

Guilbert, W. y Torres, N. (2001). Intento suicida y funcionamiento familiar. Revista Cubana de Medicina General Integral, 17, 452460.

Habib, C., Santoro, J., Kremer, P., Toumbourou, J., Leslie, E. y Williams, J. (2010). The importance of family management, closeness with father and family structure in early adolescent alcohol use. Addiction, 105, 1750-1758. doi: 10.1111/j.1360-0443.2010.03021.x.

Hemovich, V. y Crano, W. D. (2009). Family structure and adolescent drug use: An exploration of single-parent families. Substance Use \& Misuse, 44, 2099-2113. doi: 10.3109/10826080902858375.

Herrera, P. M. y Avilés, K. (2000). Factores familiares de riesgo en el intento suicida. Revista Cubana de Medicina General Integral, 16, 134-137.

Hetherington, E. M., Bridges, M. y Insabella, G. M. (1998). What matters? What does not? Five perspectives on the association between marital transitions and children's adjustment. American Psychologist, 53, 167-184.

Hoffman, J. P. (1994). Investigating the age effects of family structure on adolescent marijuana use. Journal of Youth and Adolescence, 23, 215-235. doi: 10.1007/BF01537446.

Hoffman, J. P. (2002). The community context of family structure and adolescent drug use. Journal of Marriage and Family, 64, 314-330. doi: 10.1111/j.1741-3737.2002.00314.x. 
Hoffman, J. P. (1995). The effects of family structure and family relations on adolescent marijuana use. International Journal of the Addictions, 30, 1207-1241.

Hoffman, J. P. y Johnson, R. A. (1998). A national portrait of family structure and adolescent drug use. Journal of Marriage and the Family, 60, 633-645. doi: 10.2307/353534.

Hollist, D. R. y McBroom, W. H. (2006). Family structure, family tension, and self-reported marijuana use: A research finding of risky behavior among youths. Journal of Drug Issues, 36, 975-998.

Hussong, A., Bauer, D. y Chassin, L. (2008). Telescoped trajectories from alcohol initiation to disorder in children of alcoholic parents. Journal of Abnormal Psychology, 117, 63-78. doi: 10.1037/0021843X.117.1.63

Hussong, A. M. y Chassin, L. (2002). Parent alcoholism and the leaving home transition. Development and Psychopathology, 14, 139-157. doi: $10.1017 /$ S0954579402001086.

Hussong, A. M., Curran, P. J. y Chassin, L. (1998). Pathways of risk for accelerated heavy alcohol use among adolescent children of alcoholic parents. Journal of Abnormal Child Psychology: An Official Publication of the International Society for Research in Child and Adolescent Psychopathology, 26, 453-466. doi: 10.1023/A:1022699701996.

Jansen, P., Richter, L. M., Griesel, R. D. y Joubert, J. (1990). Glue sniffing: A description of social, psychological and neuropsychological factors in a group of South African "street children". South African Journal of Psychology, 20, 150-158.

Jeynes, W. H. (2001). The effects of recent parental divorce on their children's consumption of alcohol. Journal of Youth and Adolescence, 30, 305-319. doi: 10.1023/A:1010440111698.

Jeynes, W. H. (2002). The predictive value of parental family structure on attitudes regarding premarital pregnancy and the consumption of marijuana. Journal of Human Behavior in the Social Environment, 6, 1-16. doi: 10.1300/J137v06n01_01.

Justicia, M. J. y Cantón, J. (2011). Conflictos entre padres y conducta agresiva y delictiva en los hijos. Psicothema, 23, 20-25.

Kierkus, C. A. y Hewitt, J. D. (2009). The contextual nature of the family structure/delinquency relationship. Journal of Criminal Justice, 37, 123-132. doi: 10.1016/j.jcrimjus.2009.02.008.

Kirby, J. B. (2006). From single-parent families to step families: Is the transition associated with adolescent alcohol initiation? Journal of Family Issues, 27, 685-711. doi: 10.1177/0192513×05284855.

Kirby, J. B. (2002). The influence of parental separation on smoking initiation in adolescents. Journal of Health and Social Behavior, 43, 56-71. doi: $10.2307 / 3090245$.

Komarovsky, M. y Willard, W. (1945). Studies of the family. American Journal of Sociology, 50, 443-451.

Kristjansson, A. L., Sigfusdottir, I. D., Allegrante, J. P. y Helgason, A. R. (2009). Parental divorce and adolescent cigarette smoking and alcohol use: Assessing the importante of family conflict. Acta Pediatrica, 98, 537-542. doi: 10.1111/j.1651-2227.2008.01133.x.

Ledoux, S., Miller, P., Choquet, M. y Plant, M. (2002). Family structure, parent-child relationships, and alcohol and other drug use among teenagers in France and the United Kingdom. Alcohol \& Alcoholism, 37, 52-60. doi: 10.1093/alcalc/37.1.52.

Locke, H. J. (1940). Mobility and family disorganization. American Sociological Review, 5, 489-494.

Maccoby, E. E. (1992). The role of parents in the socialization of children: a historic overview. Develpmental Psycholocy, 28, 10061017.

Miller, P. (1997). Family structure, personality, drinking, smoking and illicit drug use: A study of UK teenagers. Drug and Alcohol Dependence, 45, 121-129. doi: 10.1016/S0376-8716(97)01345-8.

Mio, J. S., Nanjundappa, G., Verleur, D. E. y de Rios, M. D. (1986). Drug abuse and the adolescent sex offender: A preliminary analysis. Journal of Psychoactive Drugs, 18, 65-72.

Neff, J. A. (1994). Adult children of alcoholic or mentally ill parents: Alcohol consumption and psychological distress in a triethnic community study. Addictive Behaviors, 19, 185-197. doi: 10.1016/0306-4603(94)90042-6.

Neisen, J. H. (1993). Parental substance abuse and divorce as predictors of injection drug use and high risk sexual behaviors known to transmit HIV. Journal of Psychology \& Human Sexuality, 6, 29-49. doi: 10.1300/J056v06n02_03.

Nunes-Costa, R. A., Lamela, D. J. P. V., y Figueiredo, B. F. C. (2009). Psychosocial adjustment and physical health in children of divorce. Jornal de Pediatria, 85, 385-396. doi: 10.1590/S002175572009000500004.

Otten, R., Engels, R. C. M. E., van de Ven, M. O. M. y Bricker, J. B. (2007). Parental smoking and adolescent smoking stages: The role of parents' current and former smoking, and family structure. Journal of Behavioral Medicine, 30, 143-154. doi: 10.1007/s10865006-9090-3.

Petraitis, J., Flay, B. R., Miller, T. O., Torpy, E. J., y Greiner, B. (1998). Illicit substance use among adolescents: A matrix of prospective predictors. Substance Use \& Misuse, 33, 2561-2604. doi: 10.3109/10826089809059341.

Ritter, J., Stewart, M., Bernet, C., Coe, M. y Brown, S. A. (2002). Effects of childhood exposure to familial alcoholism and family violence on adolescent substance use, conduct problems, and self-esteem. Journal of Traumatic Stress, 15, 113-122. doi: 10.1023/A:1014803907234.

Sprey, J. (1966). Family disorganization: Toward a conceptual clarification. Journal of Marriage and Family, 28, 398-406. doi: $10.2307 / 349535$.

Suh, T., Shütz, C. G. y Johanson, C. (1996). Family structure and initiating non-medical drug use among adolescents. Journal of Child \& Adolescent Substance Abuse, 5, 21-36. doi: 10.1300/ J029v05n03_02.

Thompson, R. G., Lizardi, D., Keyes, K. M. y Hasin, D. S. (2008). Childhood or adolescent parental divorce/separation, parental history of alcohol problems, and offspring lifetime alcohol dependence. Drug and Alcohol Dependence, 98, 264-269. doi: 10.1016/j.drugalcdep.2008.06.011.

Tomori, M., Zalar, B., Kores Plesnicar, B., Ziherl, S. y Stergar, E. (2001). Smoking in relation to psychosocial risk factors in adolescents. 
European Child \& Adolescent Psychiatry, 10, 143-150. doi: 10.1007/s007870170038.

Turner, A. P., Larimer, M. E. y Sarason, I. G. (2000). Family risk factors for alcohol-related consequences and poor adjustment in fraternity and sorority members: Exploring the role of parentchild conflict. Journal of Studies on Alcohol, 61, 818-826.

Tyler, K. A. (2006). A qualitative study of early family histories and transitions of homeless youth. Journal of Interpersonal Violence, 21, 1385-1393. doi: 10.1177/0886260506291650.

Velleman, R. D. B., Templeton, L. J. y Copello, A. G. (2005). The role of the family in preventing and intervening with substance use and misuse: A comprehensive review of family interventions, with a focus on young people. Drug and Alcohol Review, 24,93-109. doi: 10.1080/09595230500167478.

Wagner, K. D., Ritt-Olson, A., Soto, D. W. y Unger, J. B. (2008). Variation in family structure among urban adolescents and its effects on drug use. Substance Use \& Misuse, 43, 936-951. doi: $10.1080 / 10826080701801550$.

Weintraub, S. A. (1990). Children and adolescents at risk for substance abuse and psychopathology. International Journal of the Addictions, 25, 481-494.

Wolfinger, N. H. (1998). Effects of parental divorce on adult tobacco and alcohol consumption. Journal of Health and Social Behavior, 39, 254-269. doi: 10.2307/2676316.

Wu, L. L. y Martinson, B. C. (1993). Family structure and the risk of a premarital birth. American Sociological Review, 58, 210-232. doi: $10.2307 / 2095967$.

Yabiku, S. T., Dixon, A., Okamoto, S. K., Marsiglia, F. F. y Kulis, S. (2007). The effect of neighborhood context on the drug use of American Indian youth of the Southwest. Journal of Ethnicity in Substance Abuse, 6, 181-204.

Yabiku, S., Kulis, S., Marsiglia, F. F., Lewin, B., Nieri, T. y Hussaini, S. (2007). Neighborhood effects on the efficacy of a program to prevent youth alcohol use. Substance Use \& Misuse, 42, 65-87. doi: 10.1080/10826080601094264.

Zucker, R. A., Davies, W. H., Kincaid, S. B., Fitzgerald, H. E. y Reider, E. E. (1997). Conceptualizing and scaling the developmental structure of behavior disorder: The lifetime alcohol problems score as an example. Development and Psychopathology, 9, 453-471. doi: $10.1017 /$ S0954579497002125. 